\title{
Desain Literasi Budaya dalam Pembelajaran Bahasa Indonesia di Perguruan Tinggi
}

\author{
Helaluddin \\ Universitas Islam Negeri (UIN) Sultan Maulana Hasanuddin Banten \\ helaluddin@uinbanten.ac.id
}

\begin{abstract}
Abstrak: Program literasi budaya merupakan salah satu dari enam literasi dasar yang dicanangkan oleh World Economic Forum pada tahun 2015, yaitu literasi baca tulis, literasi numerasi, literasi sains, literasi digital, literasi finansial, dan literasi budaya dan kewargaan. Literasi budaya merupakan kemampuan setiap individu dalam memahami dan bagaimana seharusnya bersikap terhadap kebudayaannya sebagai identitas bangsa. Dengan kata lain, literasi budaya atau keaksaraan budaya merupakan pengetahuan, perspektif, dan kontribusi dari sekumpulan budaya yang nantinya digunakan dalam proses membaca dan menulis bagi peserta didik. Makalah ini mengangkat tentang arti pentingnya literasi budaya bagi mahasiswa di perguruan tinggi. Di samping itu, makalah ini juga menjabarkan tentang skenario pembelajaran literasi budaya dalam Mata Kuliah Bahasa Indonesia.
\end{abstract}

Kata Kunci: literasi, literasi budaya, mata kuliah bahasa Indonesia

Abstract: The cultural literacy program is one of the six basic literacies proclaimed by the World Economic Forum in 2015. Foundational literacies are literacy, numeracy, scientific literacy, ICT literacy, financial literacy, and cultural and civic literacy. Cultural literacy is someone's ability in understanding his culture and how to behave towards his culture as his nation's identity. In other words, cultural literacy is the knowledge, perspectives, and contributions of a set of cultures that will be used by the learners in the process of reading and writing. This paper highlights the advantages of cultural literacy for university students. In addition, this paper also elaborates the teaching scenario of cultural literacy in Indonesian language course.

Keywords: literacy, cultural literacy, Indonesian language course

\section{Pendahuluan}

Perkembangan pendidikan dari tahun ke tahun terus bergerak secara dinamis. Berbagai isu global tentang pendidikan berkembang pesat seiring dengan laju perubahan zaman. Hingga pada akhirnya era revolusi industri 4.0 siap memberi tantangan baru bagi dunia pendidikan dibalik derasnya arus informasi dan perubahan teknologi saat ini. Era ini memberikan begitu banyak tantangan yang harus dihadapi oleh peserta didik. Tantangan tersebut tidak hanya terfokus pada kecerdasan kognitif semata tetapi juga kecerdasan lain yang lebih kompleks. 
Memperbincangkan tentang pendidikan, tentu tidak terlepas dari faktor individu manusia dan kaitannya dengan lingkungan sosial. Hal terpenting yang menjadi fokus pendidikan saat ini adalah sikap dan kemampuan seseorang dalam menghadapi ragamnya budaya yang ada. Sudah menjadi garisnya jika dunia ini dihuni manusia dengan berbagai latar belakang, suku, agama, warna kulit, pandangan, dan lain-lain. Untuk itulah, pendidikan dipandang penting dalam memberikan pemahaman tentang keberagaman tersebut.

Indonesia merupakan negara dengan tingkat keberagaman yang tinggi. Berbagai suku, agama, bahasa, dan budaya begitu beragam yang hidup saling berdampingan sejak dari zaman dulu. Namun, ada hal yang harus menjadi perhatian kita tentang keberagaman tersebut. Pada satu sisi, pluralisme di Indonesia memiliki potensi yang luar biasa dalam memperkaya kehidupan bermasyarakat namun di sisi lain juga memiliki potensi sebagai pemicu terjadinya konflik sosial (Supriyatno: 2016).

Berkaca pada kasus yang terjadi di Amerika Serikat, konflik terjadi lebih banyak dilatarbelakangi oleh perbedaan warna kulit, yaitu dominasi orang-orang kulit putih terhadap masyarakat kulit hitam. Pada sejarahnya, masyarakat kulit hitam menjadi masyarakat kelas dua yang tidak mendapatkan prioritas dalam ruang publik di Amerika pada saat itu. Ketimpangan-ketimpangan inilah yang dikampanyekan oleh beberapa tokoh dalam mendapatkan kesetaraan sebagai warga negara Amerika.

Jika ditilik ke dalam negara kita, Indonesia tidak pernah mengalami kejadian konflik-konflik yang disebabkan oleh perbedaan warna kulit. Namun bukan berarti Indonesia bebas dari kondisi seperti itu. Boleh dikatakan justru Indonesia mengalami banyak kejadian yang lebih ironis. Konflik terjadi tidak hanya antar-kelompok tetapi juga sering terjadi dalam satu kelompok. Misalkan, konflik antar-umat Islam dalam menghadapi perbedaan pemahaman agamanya.

Berbagai kasus yang terjadi belakangan ini diyakini sebagai bentuk ketidakpedulian individu terhadap adanya perbedaan yang ada. Mereka cenderung apatis dan menganggap dirinya dan alirannya merupakan satu-satunya yang benar dan terbaik. Dalam hal agama misalnya, semakin banyak penganut suatu agama yang menerapkan teologi ekslusif dalam 
memahami ajarannya daripada teori inklusif-pluralis (Abidin: 2013). Mereka menganggap agamanya sebagai satu-satunya keyakinan yang benar dan keyakinan orang lain sebagai aliran yang salah dan sesat. Hingga pada akhirnya, mereka cenderung mudah menghujat, menghina, dan melakukan perbuatan-perbuatan yang tidak terpuji terhadap orang lain atau golongan yang berbeda darinya.

Sisi negatif adanya keberagaman budaya di Indonesia dapat menjadi pemicu konflik vertikal dan konflik horizontal. Konflik vertikal dapat terjadi jika antar-kelompok tidak ada sikap saling menghargai dan menghormati sehingga berpeluang terjadinya praktik hegemoni terhadap kelompok yang lebih kecil tau kelompok minoritas (Rosmawaty: 2015). Lebih lanjut, konflik horizontal dapat terjadi pula jika dalam sebuah interaksi antar-kelompok di mana salah satu kelompok merasa memiliki superioritas terhadap kelompok lainnya. Bahkan kelompok superiotas ini menganggap hanya komunitasnyalah yang paling baik, benar, dan utama sedangkan kelompok yang lain hanyalah pelengkap semata.

Lebih lanjut, dalam memasuki era banjir informasi saat ini, seorang mahasiswa dituntut untuk memiliki kemampuan literasi di berbagai aspek. Literasi tersebut tidak hanya dimaknai sebatas "melek huruf" tetapi juga kemampuan dalam memahami segala hal yang memegang peranan penting dalam kehidupan manusia. Seiring perkembangan zaman, istilah literasi berkembang dan meluas ke segala bidang, seperti literasi teknologi, literasi digital, literasi keuangan, literasi kesehatan, dan lain-lain. Menurut World Economic Forum 2015, ada enam jenis literasi dasar atau foundational literacies yang harus dikuasai oleh generasi era revolusi industri 4,0 saat ini, yaitu literasi baca tulis (literasi dasar), literasi numerasi, literasi sains, literasi digital, literasi finansial, dan literasi budaya dan kewargaan.

Berbicara tentang tingkat literasi (keberliterasian) pada suatu bangsa, tidak terlepas dari keterampilan yang dibutuhkan oleh para lulusan pada abad ke-21. Masih menurut pemaparan WEF (World Economic Forum: 2015) tentang New Vision for Education: Unlocking the Potential of Technology bahwa ada tiga jenis keterampilan abad ke-21, yaitu literasi-literasi dasar, kompetensi, dan kualitas karakter. Berbagai kompetensi yang harus dikuasai oleh peserta didik saat ini adalah: (1) 
critical thinking dan problem-solving, (2) kreativitas, (3) komunikasi, dan (4) kolaborasi. Kualitas karakter merupakan hal-hal yang harus dimiliki peserta dalam menyikapi perubahan lingkungannya. Kualitas karakter ini mencakup: (1) rasa ingin tahu, (2) inisiatif, (3) ulet atau gigih, (4) kemampuan beradaptasi, (5) kepemimpinan, dan (6) kepedulian sosial dan budaya. Sedangkan salah satu literasi dasar yang harus dimiliki oleh peserta didik adalah literasi budaya. Literasi ini merupakan kemampuan seseorang dalam memahami perbedaan budaya yang ada di sekelilingnya sehingga timbul kepedulian terhadap keanekaragaman tersebut.

Di sisi lain, Hallissy, M., Butler, D., Hurley, J., dan Marshall (2013) mengungkapkan bahwa setiap pekerja atau lulusan perguruan tinggi harus memiliki beberapa kompetensi agar dapat bersaing di dunia kerja. Beberapa kompetensi yang dimaksud adalah memiliki pengetahuan lebih tentang dunia saat ini, berpikir di luar kebiasaan (out of the box), menyikapi dengan cerdas setiap informasi baru, mengembangkan keterampilan good people, mampu menyelesaikan problematika yang kompleks, dan memiliki berbagai keterampilan hidup.

Bila kita cermati lebih mendalam, beberapa tahun belakangan ini semakin meningkat jumlah kasus atau kejadian-kejadian yang didasari oleh ketidakharmonisan dalam bermasyarakat. Perselisihan hingga tindak kekerasan baik di dunia maya maupun dunia nyata mayoritas disebabkan oleh isu-isu tentang tidak adanya sikap toleransi terhadap keberagaman. Dengan berkembangnya media sosial, seolah-olah kebebasan berekspresi yang berlebihan kian tak terkontrol. Berbagai ujaran kebencian dan ujaran perundungan atau bullyng semakin beredar luas. Masyarakat media sosial atau netizen seolah-oleh memiliki hak penuh dalam menghakimi dan menuding pendapat dan pilihan hidup orang lain. Mereka seakan tak mengizinkan orang lain berbeda dengan pilihannya. Indikator ketidaksanggupan individu dalam menghargai perbedaan pilihan maupun pendapat merupakan sisi lain dari kegagalan dalam pendidikan di Indonesia.

Literasi budaya tidak dapat dielakkan begitu saja dalam kehidupan manusia. Adanya keberagaman fisik, adat, agama, bahasa, dan lainlainnya mengharuskan setiap individu untuk saling memahami. Artinya, keberagaman merupakan hal pasti dalam peradaban manusia sehingga 
mutlak diperlukan pendidikan tentang literasi budaya. Seharusnya pendidikan berbasis literasi budaya sudah harus ditanamkan semenjak dini bagi peserta didik. Pendidikan tentang budaya ini dimaksudkan agar para peserta didik mampu menempatkan dirinya dalam lingkungan masyarakat yang pluralis.

Dewasa ini, multikultural telah menjadi isu dunia dan merupakan konsekuensi dari globalisasi. Dengan adanya globalisasi, manusia akan menghadapi berbagai perbedaan seperti perbedaan pandangan atau pendapat, nilai, cara berkomunikasi, dan kebiasaan yang lebih kompleks baik secara lokal maupun global. Mengingat pentingnya pendidikan keberagaman budaya, tidak mengherankan jika di beberapa perguruan tinggi luar negeri sudah secara terbuka menyatakan multikultural sebagai identitas pendidikannya. Artinya, kampus tersebut menerima mahasiswa dari berbagai latar belakang budaya dan negara yang berbeda.

Tantangan kian berat dengan diberlakukannya Masyarakat Ekonomi ASEAN (MEA) di Kawasan Asia Tenggara. Kebijakan regional ini berpotensi besar menciptakan interaksi antar bangsa-bangsa dengan berbagai kultur dan kebiasaan. Hal ini terjadi karena dalam perdagangan bebas, produk-produk dan masyarakat dari negara lain memiliki peluang besar untuk datang ke negara lain. Kondisi ini tentu harus diantisipasi dengan menyiapkan generasi yang memiliki pengetahuan dan keterampilan hidup, salah satunya dengan literasi budaya. Melek budaya akan mengantarkan individu untuk sukses dalam eksistensinya di era MEA.

Menurut paparan para ahli yang dicantumkan dalam sebuah buku oleh Kementerian Pendidikan Finlandia berjudul Education for Global Responsibility-Finnish Perspectives menyatakan bahwa literasi budaya diartikan sebagai kompetensi interkultural (antar-budaya) yang dalam beberapa referensi memiliki persamaan istilah dengan intercultural awareness (kepedulian antarbudaya), intercultural sensitivity (sensitivitas antarbudaya), intercultural adaptation (adaptasi antarbudaya), dan intercultural effectiveness (keefektifan antarbudaya). Lebih lanjut, mereka menyebut bahwa literasi budaya merupakan sebuah tujuan dari pendidikan global. 
Literasi budaya sangat penting peranannya dalam menjaga dan membangun hubungan sosial. Artinya, timbulnya ekslusivitas kelompok dan sikap intoleran dapat dikikis dengan meningkatkan keberliterasian dalam budaya. Merebaknya kasus diskriminasi dan penghinaan terhadap kelompok minoritas merupakan salah satu bentuk tidak adanya literasi budaya yang tertanam dalam tiap-tiap anggota masyarakat. Mengingat pentingnya literasi budaya, perlu dilakukan upaya yang nyata khususnya dalam proses pembelajaran di perguruan tinggi. Salah satunya dengan mendesain sebuah pembelajaran berbasis literasi budaya dalam Mata Kuliah Bahasa Indonesia.

\section{Budaya Literasi dan Literasi Budaya}

Sebagai tahapan awal, ada baiknya kita membedakan definisi antara budaya literasi dan literasi budaya. Bahkan, kita dapat mengulas lebih rinci lagi tentang istilah budaya dan literasi. Dalam sebuah literatur, budaya dapat digambarkan sebagai gunus es. Artinya, ada aspek-aspek budaya yang terlihat di permukaan namun ada pula yang tidak tampak di permukaan. Bagian-bagian budaya yang dapat dilihat dengan mudah melalui mata kita antara lain pakaian adat, bahasa, makanan, perayaan, ritual, dan lain-lain. Bagian-bagaian budaya yang tak tampak adalah nilai, status, peran, persepsi, tradisi, kepercayaan, dan bentuk-bentuk pemikiran.

Budaya literasi adalah proses pembiasaan terhadap aktivitas membaca dan menulis. Budaya literasi dapat dikategorikan sebagai tingkat literasi awal atau literasi dasar. Istilah kata "literasi" sendiri memang bersifat fleksibel dan cenderung berkembang dari masa ke masa. Seperti yang telah diulas di awal bahwa literasi dimaknai sebagai sebuah kondisi suatu masyarakat yang telah melek huruf. Seiring dengan perkembangan zaman, istilah literasi mengalami perluasan makna yang disesuaikan dengan bidang-bidang tertentu, seperti literasi sains, literasi finansial, literasi digital, dan lain-lain.

Berbagai definisi tentang literasi budaya juga banyak di temui di berbagai literatur. Menurut Hadiansyah dkk. (Badan Pengembangan dan Pembinaan Bahasa) literasi budaya adalah kebiasaan seseorang dalam berpikir yang diikuti dengan aktivitas baca-tulis yang pada ujungnya akan 
menekankan pada proses berpikir kritis, pemecahan masalah, kreatif, dan pengembangan ilmu pengetahuan (2016). Literasi budaya juga dimaknai sebagai kemampuan dalam memahami, implementasi, dan menetapkan perbedaan dan persamaan sikap, kebiasaan, kepercayaan, dan komunikasi seseorang (Riani dkk.: 2018).

Istilah literasi budaya dipopulerkan oleh Hirsch dalam bukunya berjudul Cultural Literacy: What Every American Needs to Know. Menurut Hirsch (1987) literasi budaya dikembangkan karena setiap orang tidak dapat belajar membaca, menulis, dan komunikasi dengan orang lain sebagai keterampilan yang terpisah dari pengetahuan secara kultural. Lebih lanjut, Aprinta (2013) menguraikan bahwa literasi budaya merupakan pengetahuan seseorang tentang sejarah, kontribusi, dan perspektif terhadap budaya lain yang berbeda (termasuk juga budaya sendiri) yang digunakan dalam aktivitas membaca dan menulis.

Pada perkembangannya, literasi budaya memiliki konsep yang sedikit berbeda dari para ahli. Menurut García Ochoa (2016) literasi budaya merupakan sebuah konsep ambang batas atau threshold concept. Artinya, konsep ini diibaratkan memasuki atau melewati sebuah portal dari sebuah perspektif yang terbuka dan membiarkan hal-hal sebelumnya dianggap tidak timbul lagi. Lebih lanjut, literasi budaya juga diartikan sebagai modus operandi yang menyoroti komunikasi, perbandingan dan kritik, membawa ide-ide bersama dalam kolaborasi interdisipliner dan internasional.

Definisi yang sedikit berbeda dikemukakan oleh Saepudin dkk. (2018) yang menyatakan bahwa ada keterkaitan antara literasi informasi dan literasi budaya. Literasi informasi dimaknai sebagai kemampuan seseorang dalam mencari informasi yang akurat, cepat, tepat, dan arif dalam mengomunikasikan informasi tersebut. Di sisi lain, definisi literasi budaya adalah kemampuan seseorang dalam mencari dan menggali informasi yang terdapat dalam budaya.

Bila dikaitkan dengan bahasa, literasi budaya juga dapat dikatakan memiliki keterkaitan yang sangat erat. Menurut Kalantzis dikutip Barrette and Paesani: 2017) teks dalam bahasa didefinisikan secara luas sebagai sebuah tulisan, oral, visual atau multimodal sebagai pusat konsepsi literasi budaya. Hal ini disebabkan oleh teks yang 
merepresentasikan praktik secara signifikan tentang sebuah realita sosial dan memiliki tujuan sosial. Dari beberapa pemaparan di atas, dapat disimpulkan bahwa literasi budaya merupakan kecakapan abad ke-21 maupun era revolusi industri 4.0 yang menuntut peserta didik untuk memahami dan bagaimana seharusnya bersikap terhadap keberagaman budaya baik di Indonesia maupun secara global.

Menurut Muller dikutip Halbert \& Chigeza (2015) menguraikan bahwa sesorang yang memiliki literasi budaya memiliki kriteria berikut: (1) memahami kompleksitas budaya dan semua budaya yang berisi kekuatan, kelemahan, dan paradoksnya serta perubahan budaya yang tidak dapat dihindari, (2) mampu menganalisis atribut budaya sendiri, mengidentifikasi dan mendekonstruksi stereotip yang ada, (3) peduli terhadap komponenen budaya yang mencakup budaya universal, internal (berbasis nilai), dan eksternal (gaya hidup) dan interrelasi bahasa dan budaya yang kompleks, (4) lebih menyukai menjadi relativis budaya daripada fundamentalis budaya.

Literasi budaya memiliki banyak manfaat dalam aspek kehidupan. Salah satunya berperan penting dalam membangun bangsa yang beradab. Melalui literasi budaya diharapkan kita dapat meminimalisasi sikap individualis, menghindari ego kelompok, menghindari kesalahpahaman, dan mendorong kerja sama (Damaianti, Damaianti \& Mulyati: 2017). Sebagai individu, literasi budaya berfungsi dalam membantu interaksi secara baik dari berbagai latar belakang yang berbeda. Artinya, literasi budaya ini membantu dalam mengembangkan perspektif budaya yang kritis, jika kita termasuk bagian dari kelompok dominan maka kita harus melihat orang lain dari kelompok marjinal sebagai budaya yang normal dengan mengevaluasi kelebihan dan keterbatasan budaya tersebut (Flavell: 2013).

\section{Pendidikan Literasi Budaya di Indonesia}

Mengingat pentingnya peranan literasi budaya, pemerintah perlu mengembangkan suatu pola atau sistem dalam menerapkan literasi budaya di dunia pendidikan. Salah satu kebijakan pemerintah dalam kasus ini adalah dengan penerapan kurikulum 2013. Kurikulum ini merupakan kurikulum pengganti KTSP (Kurikulum Tingkat Satuan 
Pendidikan) yang diyakini mampu memajukan pendidikan di Indonesia. Dalam kurikulum 2013, aspek literasi budaya sudah mulai diperkenalkan dengan aspek-aspek lainnya, yaitu pendidikan karakter dan pengembangan budaya (Rokhmawan \& Firmansyah: 2017).

Isu-isu penting yang diusung dalam pendidikan saat ini memang lebih banyak diisi dengan konten pendidikan karakter dan budaya. Kondisi ini bukanlah hal yang baru dalam dunia pendidikan. Sebelumnya, pendidikan berbasis budaya juga telah digaungkan oleh para pakar pendidikan dunia, khususnya para pakar aliran esensialisme. Teori pendidikan ini merupakan pemahaman bahwa sebuah pendidikan harus dilandasi oleh hal-hal yang bersifat fundamental, salah satunya adalah landasan budaya lama yang telah teruji keberadaannya (Helaluddin: 2018).

Pada dasarnya pendidikan berbasis budaya ataupun pendidikan multikultural di selolah/kampus dapat dilakukan dalam beberapa aspek. Beberapa aspek tersebut adalah: (1) integrasi konten, (2) proses merekonstruksi pengetahuan, (3) penyesuaian metode pembelajaran di kelas, (4) pengurangan terhadap prasangka, dan (5) penguatan budaya sekolah dan struktur sosial (Banks dikutip Rosmawaty: 2015).

Menurut Kementerian Pendidikan dan Kebudayaan dengan bukunya yang berjudul Materi PEndukung Literasi Budaya dan Kewargaan (2017) ada beberapa strategi yang digunakan dalam memperkuat literasi budaya di sekolah. Strategi-strategi tersebut adalah: (1) kegiatan bengkel kreatif berbahasa daerah, (2) residensial, (3) pengenalan ketahanan nasional, (4) pelatihan guru dan tenaga kependidikan, (5) pelatihan pembuatan permainan edukatif, dan (6) forum diskusi bagi warga sekolah.

Literasi budaya dikaitkan erat dengan pembelajaran bahasa. Bahkan, beberapa ahli berpendapat bahwa mengajarkan sebuah bahasa berarti juga mengajarkan kebudayaan juga, khususnya dalam pembelajaran bahasa asing. Lebih lanjut, Kucer dikutip Barrette and Paesani (2018) mengungkapkan bahwa definisi literasi budaya mencakup juga tentang pemahaman bentuk bahasa dan konvensinya, bagiamana menyampaikan sebuah makna, bagaimana membuat kesimpuan/inferensi, berpikir secara kritis, merefleksikan pada suatu pembelajaran, dan kepedulian 
secara sosial-budaya tentang situasi sebenarnya pada bahasa dan komunikasi.

Selain melalui pembelajaran bahasa, literasi budaya juga dapat diintegrasikan dalam pembelajaran Mata Pelajaran Seni dan Budaya. Sebuah studi terkait hal ini dilakukan oleh Desyandri (2018) yang menyatakan bahwa menumbuhkembangkan literasi budaya kepada siswa-siswa agar tidak tercerabut dari budaya lokal Minang dapat dilakukan melalui pembelajaran Seni di sekolah dasar. Siswa diajarkan tentang nilai-nilai kearifan lokal yang terkandung dalam lagu-lagu Minang. Dengan nilai-nilai kearifan lokal tersebut diharapkan siswa akan semakin mengenali budaya lokalnya sebagai bentuk perwujudan pendidikan literasi budaya di sekolah.

Berdasarkan pentingnya literasi budaya tersebut, maka perlu ditingkatkan kompetensi pendidik dalam meperkenalkan keberagaman budaya dalam proses pendidikan di sekolah. Sesuai dengan perkembangan zaman saat ini, seorang pendidik, baik guru dan dosen harus memiliki berbagai keterampilan dalam mengajarkan pada peserta didiknya mencapai kompetensi abad ke-21. Dengan keterampilanketerampilan yang dimilikinya, seorang pengajar harus memperkenalkan tentang krativitas, berpikir kritis, mengatasi masalah, membuat keputusan yang tepat, komunikasi dan kolaborasi dalam bekerja, literasi informasi, dan lain-lain kepada peserta didik (Auzinna: 2018). Pada level perguruan tinggi, literasi budaya juga sangat diperlukan dalam rangka membentuk lulusan untuk hidup dan bekerja di lingkungan yang transkultural dan transdisipliner. Seperti yang telah kita ketahui, saat ini telah memasuki era dimana para mahasiswa harus terlibat langsung dalam interaksi dan kolaborasi antar-budaya dan multi-budaya. Menurut García Ochoa dkk. (2016) institusi pendidikan tinggi harus menyiapkan lulusan dengan keterampilan mobilitas dan fleksibilitas untuk mampu bekerja secara efisien di lingkungan transkultural dan transdisipliner. Beberapa istilah dengan nuasa berbeda tentang ulasan tersebut antara lain (1) kompetensi global atau global competency, (2) cosmopolitansm, (3) global citizen, dan (4) cosmopolitan capital. 


\section{Desain Literasi Budaya dalam Pembelajaran Bahasa Indonesia}

Dalam kaitannya dengan pembelajaran Mata Kuliah Bahasa Indonesia di perguruan tinggi, literasi budaya dapat diintegrasikan dalam konten pembelajarannya. Secara umum, ranah Mata Kuliah Bahasa Indonesia di perguruan tinggi terdiri atas, materi pengetahuan bahasa, keterampilan membaca, menulis, dan berbicara. Pada artikel ini, diuraikan konten literasi budaya ke dalam tiga ranah, yaitu keterampilan membaca, menulis, dan berbicara.

Pertama, literasi budaya dapat diintegrasikan dalam pembelajaran keterampilan membaca di Mata Kuliah Bahasa Indonesia. Dengan aktivitas membaca berbagai teks yang bermuatan budaya dapat berfungsi sebagai media pengenalan terhadap berbagai budaya di Indonesia maupun luar negeri. Keanekaragaman agama, adat istiadat, bahasa daerah, seni daerah, dan lain-lain dapat dikemas dalam berbagai teks dengan tujuan untuk menambah pengetahuan mahasiswa tentang budaya di Indonesia.

Untuk level perguruan tinggi, topik atau tema teks dapat pula berkaitan dengan budaya luar yang mungkin memiliki perbedaan yang cukup kontradiktif dengan budaya kita. Tujuannya adalah untuk membentuk pemahaman kepada mereka bahwa budaya di setiap belahan dunia berbeda-beda dan kadang bertolak belakang. Untuk itulah, diperlukan sikap menghargai dan menghormati pada perbedaan tersebut. Teks tentang konten budaya, baik budaya lokal maupun budaya luar dapat diseimbangkan porsinya dengan teks yang bermuatan kesehatan, ekonomi, politik, dan lain-lainnya.

Kegiatan membaca lainnya yang dapat dikaitkan dengan literasi budaya adalah membaca karya sastra. Melalui kegiatan ini, mahasiswa diajak untuk membaca dan menganalisis beberapa karya sastra, baik novel, cerpen, maupun karya sastra lainnya yang mengandung nilai-nilai budaya. Dosen dapat menugaskan mahasiswa membaca beberapa karya sastra yang telah diidentifikasi sebelumnya memiliki konten yang sarat dengan nilai-nilai budaya di dalam ceritanya.

Kedua, desain literasi budaya juga dapat dikemas dalam proses pembelajaran menulis, baik menulis akademik maupun menulis populer. 
Pada pembelajaran menulis paragraf atau esai misalnya, dosen dapat menyajikan contoh esai yang berkonten budaya. Misalkan tentang tradisi di daerah tertentu yang melakukan ritual disertai dengan ulasan-ulasan yang bersifat argumentatif. Selanjutnya, pengajar meminta mahasiswa untuk menulis esai dengan pola yang sama dengan mengambil tema atau topik dari budaya daerah lain.

Ketiga, keterampilan berbahasa yang bersifat produktif selain menulis adalah keterampilan berbicara. Keterampilan ini juga tergolong keterampilan yang sulit karena setiap individu harus mampu mengungkapkan ide dan gagasan yang ada dalam pikirannya kepada orang lain dengan menggunakan perantara bahasa yang baik dan terstruktur. Lain konteksnya jika berbicara dalam situasi nonformal. Seseorang akan lebih mudah menyampaikan ide dan perasaannya sedangkan pada situasi formal tentu kondisinya akan berbeda jauh.

Literasi budaya dapat juga diimplementasikan dalam pembelajaran berbicara, khususnya berbicara akademik. Dosen dapat memilih dan memilah materi atau konten yang bermuatan budaya dari youtube atau video.com dan disajikan di depan kelas. Bagi dosen yang hendak mengembangkan sendiri bahan ajarnya, tentu dapat juga mengembangkan materi-materi berbicara yang berorientasi pada keberagaman budaya. Pemilihan materi tentang budaya tentu dikaitkan dengan latar belakang mahasiswa ataupun dengan pertimbangan lain. Beberapa pertimbangan tersebut antara lain: (1) materi tentang budaya di sekitarnya, (2) budaya nasional, (3) budaya internasional yang sedang hangat diperbincangkan atau booming, dan lain-lain.

Terkait dengan materi berbicara akademik yang diimplementasikan dengan konten literasi budaya, Sari dan Inderawati (2014) melakukan studi untuk pembelajaran bahasa Inggris. Dalam studinya tersebut, penggunakan Model Literasi Budaya (MLB) dielaborasikan dengan penggunaan teknologi dalam mencari berbagai sumber cerita-cerita legenda di Indonesia. Melalui model ini, mahasiswa diberi kesempatan untuk menyampaikan atau berbicara di depan kelas tentang hasil diskusi dengan kelompok kecilnya.

Terakhir, literasi budaya juga dapat diimplementasikan melalui tugas-tugas mahasiswa di luar mata kuliah bahasa Indonesia. Sebagai 
contoh, mahasiswa ditugaskan untuk mementaskan pertunjukan seni dengan mengambil tema tentang budaya-budaya lokal. Sebelum pertunjukkan ditampilkan, dosen mendorong mahasiswa untuk membentuk bengkel seni di kampus sebagai wadah dalam berlatih peran dan seni pertunjukkannya. Tema-tema teater atau seni pertunjukannya dapat diambil dari cerita atau legenda dari suatu daerah tertentu. Di samping itu juga, mahasiswa dapat pula diarahkan untuk menulis cerita sendiri yang bersifat kontemporer dengan berdasarkan tragedi atau kejadian di masa kini yang tentunya masih berkaitan dengan budaya di Indonesia.

\section{Kesimpulan}

Menurut pemaparan dalam World Economic Forum 2015, ada tiga keterampilan yang harus dikuasai oleh peserta didik, yaitu literasi dasar, competences, dan character qualities. Terakit dengan literasi dasar, ada beberapa jenis literasi yang harus dikuasai oleh peserta didik pada abad ke-21 ini, yaitu literasi baca-tulis, literasi numerasi, literasi saintifik, literasi teknologi informasi dan komunikasi (TIK), literasi finansial, dan literasi budaya \& kewargaan.

Literasi budaya merupakan jenis literasi yang vital untuk ditanamkan pada peserta didik. Literasi budaya merupakan kemampuan individu dalam memahami, menghargai, dan memaknai adanya keberagaman di lingkungannya. Di era globalisasi, keberagaman budaya merupakan aspek yang tidak dapat dihindari. Bahkan, memasuki era revolusi industri 4.0 saat ini kemampuan literasi budaya mutlak diperlukan sebagai modal/bekal untuk hidup dan bekerja sebagai masyarakat global.

Dengan alasan itulah, diperlukan upaya nyata dalam mengimplementasikan literasi budaya di lembaga pendidikan, khususnya perguruan tinggi. Salah satunya dapat dilakukan dengan pengintegrasian literasi budaya dalam proses pembelajaran Mata Kuliah Bahasa Indonesia. Desain literasi budaya ini dapat dikemas dalam berbagai materi pembelajaran, seperti pada materi kompetensi membaca, menulis, dan berbicara. 


\section{Daftar Rujukan}

Abidin, Zain. Islam Inklusif: Telaah atas Doktrin dan Sejarah. Humaniora, Vol. 4, No. 2, 2013.

Aprinta, Gita. Fungsi Media Online sebagai Media Literasi Budaya bagi Generasi Muda. The Messenger, Vol. 5, No. 1, 2013.

Auziña, Anita. Teacher Competences for Facing Challenges of Globalisation in Education. Journal of Education Culture and Society, Vol. 2, No. 2, 2018. doi:10.15503/jecs20182.24.37.

Barrette, Catherine M., dan Kate Paesani. Conceptualizing Cultural Literacy through Student Learning Outcomes Assessment. Foreign Language Annals, Vol. 51, No. 2, 2018. doi:10.1111/flan.12337.

Damaianti, Vismaia S., dkk. Cultural Literacy Based Critical Reading Teaching Material with Active Reader Strategy for Junior High School. International Journal of Evaluation and Research in Education (IJERE), Vol. 6, No. 4, 2017, hlm. 312-317, http://iaesjournal.com/online/index.php/IJERE.

Desyandri. Nilai-Nilai Kearifan Lokal untuk Menumbuhkembangkan Literasi Budaya di Sekolah Dasar. Jurnal Sekolah Dasar: Kajian Teori dan Praktik Pendidikan, Vol. 27, No. 1, 2018. hlm. 1-9. doi:10.17977/um009v27i12018p001.

Flavell, H. Developing Indigenous Australian Cultural Competence: A Model for Implementing Indgenous Content into Curriculum. Journal of Teaching and Learning for Graduated Employability., Vol. 4, No. 1, 2013.

García Ochoa, Gabriel dkk. Embedding Cultural Literacy in Higher Education: A New Approach. Intercultural Education, Vol. 27, No. 6, 2016. hlm. 546-559. doi:10.1080/14675986.2016.1241551.

Hadiansyah, Firman dkk. Materi Pendukung Literasi Budaya dan Kewargaan. Jakarta: Kementerian Pendidikan dan Kebudayaan, 2017.

Halbert, Kelsey dan Philemon Chigeza. Navigating Discourses of Cultural Literacy 
Helaluddin: Desain Literasi Budaya dalam Pembelajaran Bahasa Indonesia di Perguruan Tinggi| 115

in Teacher Education. Australian Journal of Teacher Education, Vol. 40, No. 11, 2015. hlm. 155-168. doi:10.14221/ajte.2015v40n11.9.

Hallissy, M., Butler, D., Hurley, J., Marshall, K. Redesigning Education: Meeting the Challenges of the 21st Century. Brisbane: St Patrick College, 2013.

Helaluddin. Restrukturisasi Pendidikan Berbasis Budaya: Penerapan Teori Esensialisme di Indonesia. Jurnal Dimensi Pendidikan dan Pembelajaran, Vol. 6, No. 2, 2018.

Hirsch, E. D. Cultural Literacy: What Every American Needs to Know. Boston: Houghton Mifflin, 1987.

Riani, Dian dkk. Cultural Literacy Praxis in Teaching and Learning English at SMPN 14 Padang. Jakarta: UNJ, 2018.

Rokhmawan, Tristan, dan M. Bayu Firmansyah. Cultural Literacy Development Based on Local Oral-Stories as The Cultural Identity of Kebonsari Elementary School. Journal of Intensive Studies on Language, Literature, Art, and Culture (ISLLAC), Vol. 1, No. 1, 2017. hlm. 224-238.

Rosmawaty. Pengembangan Model Pembelajaran Berbasis Multikultural Pada Pembelajaran PAI. Jurnal Edukasi Kultura, Vol. 2, No. 2, 2015. doi:10.1164/rccm.200607-984PP.

Saepudin, Encang dkk. Model Literasi Budaya Masyarakat Tatar Karang di Kecamatan Cipatujah Kabupaten Tasikmalaya. Jurnal Berkala Ilmu Perpustakaan dan Informasi, Vol. 14, No. 1, 2018. doi:10.22146/bip.33315.

Sari, Fitri Suci Puspita dan Rita Inderawati. The Application of Cultural Literacy Model to Enhance Speaking Ability trough Legends for Advance Students in ELT Classroom. Journal of Social Science Research, Vol. 5, No. 2, 2014. doi:https://doi.org/10.24297/jssr.v5i2.3356.

Supriyatno, Triyo. Keberagaman Elemen Budaya Dalam Pembelajaran Pendidikan Agama Islam di Sekolah Dasar Islam di Malang. Jurnal Ulul Albab, Vol. 17, No. 2, 2016. hlm. 218-229.

WEF (World Economic Forum). New Vision for Education: Unlocking the Potential of Technology. Davos: WEF dan The Boston Consulting Group, 2015. 
116 | ESTETIK, Vol. 1 No. 2, Desember 2018 